\title{
An Unusual Occurrence of Multiple Sclerosis in a Small Rural Community
}

\author{
THOMAS JOHN MURRAY
}

SUMMARY: Ten patients with multiple sclerosis were found to have lived in close proximity in a Nova Scotia farming community of 150 people. All had drunk unpasteurized milk as children, were teetotallers, ate a high animal fat diet, and were well edacated. Of greater interest was the observation that six of the ten cases were related in two family groups.

The only time all patients lived in the community at the same time was in 1951

RÉSUMÉ: Nous avons trouvé 10 patients atteints de sclérose en plaques ayant vécu à proximité d'un village de fermiers de 150 personnes en NouvelleEcosse. Tous ont bu du lait nonpasteurisé quand ils étaient enfants, furent bien éduqués, s'abstenaient d'alcool et consommaient une diète riche en gras animal. L'observation la plus intéressante était que six des dix cas étaient reliés à l'intérieur de 2 groupes familiaux.

Le seul temps où tous les patients vécurent dans le village en même temps fut en 1951 et 1952 pendant les premières manifestations d'une épidémie de polio. and 1952 during a polio outbreak. The relationship of polio to multiple sclerosis bears further study.

The average age of the patients when they had measles was 11.8 years. Evidence suggests a link between risk of multiple sclerosis and both late onset of measles and pubertal age. Late onset of measles may be important in this cluster. Further epidemiological studies are needed to examine the age of onset of measles in M.S. cases.

La relation entre la polio et la sclérose en plaques demande une étude plus poussée.

L'âge moyen des patients quand ils ont eu la rougeole était de 11.8 ans. Ceci pourrait indiquer un lien entre le risque de sclérose en plaques et le début tardif de la rougeole et de la puberté. Le début tardif de la rougeole peut, en effet, être important dans le group que nous avons décrit. Des études épidémiologiques plus poussées sont nécessaires pour évaluer l'âge de début de la rougeole dans un plus grand nombre de cas de sclérose en plaques.
Reprint requests to: Dr. T. J. Murray, Chief of Medicine. Camp Hill Hospital, Halifax, Nova Scotia B3H 3G2.

Presented to The Royal College of Physicians and Surgeons of Canada, Winnipeg, Manitoba, January, 1975.
One of the most intriguing and puzzling aspects of multiple sclerosis is its unusual distribution in the world. There have been many studies to determine whether areas within this distribution have an unusual prevalence or incidence, but only a few community clusters have been described. Such cluster studies are of great interest in the search for information, not just to explain the local phenomenon, but possibly to provide some etiological clues to the problem of multiple sclerosis in general.

We studied 10 cases of multiple sclerosis, all within a few miles of each other in a farming area of 150 people.

\section{Community Study}

The area under study is located in Colchester County, Nova Scotia. The nearest town is Tatamagouche, about eight miles away. The region is made up of three small farming areas known as Balfron, Balmoral Mills, and The Falls, all within three square miles. A house-to-house count of the area showed that there were 27 active farms with 150 people living on them.

Through community contacts we learned of 14 possible cases of M.S. in the region; examination showed 10 cases of M.S., two siblings with muscular dystrophy, one case of amyotrophic lateral sclerosis and one untreated myasthenia gravis. All the 10 M.S. patients lived or had previously lived in or around the area of The Falls. Over a three-year period, we attempted to explain this cluster by evaluating data from interviews and examination of patients, on site visits, questionnaires 
and examination of all available records.

\section{Possible Etiological Factors:}

Various findings emerged from our study. During their childhoods there were animals in and around the homes and farms of all patients. All drank unpasteurized milk as children. All were teetotallers. The educational level of the patients was high. All ate a high animal fat diet with over $800 \mathrm{mg}$ of cholesterol per day. The average age of measles was 11.8 years. Six of the 10 cases were related in two families. The only years that all patients lived in the same vicinity at the same time were 1951 and 1952, and in 1952 there was a major polio outbreak in the region.

\section{DISCUSSION}

The presence of animals around homes, and the drinking of unpasteurized milk in childhood would not be surprising in a farming community 25 years ago. Although we were surprised to find that all patients were teetotallers, this and the fact that only one of them smoked could be due to the prevalent Scottish Presbyterian background. The educational level of the patients seemed very high. Some were schoolteachers, several had university degrees, one is an accountant, and one is an emeritus university professor. This might also be explained by the Scottish background of the patients, since the Scots have always placed a high premium on education.

The average age of the patients when they had measles was 11.8 years. This is unusually late; most children have had measles at school entry age. Perhaps the rural isolation accounts for the late age for measles, but it is of interest that Alter (1975) recently noted a generally late onset of measles in M.S. patients. The occurrence of measles around the time of puberty is of some interest since there is increasing evidence that measles is related to the development of multiple sclerosis in some way (Haire et al., 1973 and Haire et al., 1974). There is also evidence that whatever the risk factor or agent is in multiple sclerosis it is related to the pubertal age group (Poskanzer, 1968). We suggest that the age of onset of measles be evaluated in further epidemiological studies of M.S. as a possible additional clue to the cause of the disease. Perhaps the age at which one contracts a viral infection is more important than the specific agent itself.

The animal fat intake in the patients' diets is high, but an estimated average consumption of $800 \mathrm{mg} /$ day of cholesterol is not unusual for a North American diet (Guthrie, 1975). We also found similar dietary patterns among 16 multiple sclerosis patients in the Halifax area where the prevalence rate of M.S. is 21 per 100,000 population. Alter (1975) has suggested that experimental and clinical observations relating diet to increased adhesiveness of formed blood elements, biochemical alterations of central myelin, and impaired delayed hypersensitivity are plausible mechanisms linking the risk of M.S. to high animal fat consumption. Accurate determinations of cholesterol intake by history, especially in attempts to determine dietary habits in earlier life, are so uncertain that we can obtain only a rough and unreliable estimate of intake. Also, virtually all M.S. patients alter their diet in some way after they develop the disease and it becomes even more difficult to obtain information on what their previous diet had been.

Family relationships are important in this cluster study as six of the 10 cases are related in two families. In the first, a brother and sister both have multiple sclerosis. These siblings are of some interest because, although their families moved away from The Falls many years ago, both children who later developed multiple sclerosis continued to spend summers in The Falls. However, a first cousin who has never lived in The Falls also had multiple sclerosis. In the second family, there are two sisters with multiple sclerosis and a nephew with a rapidly progressive form of M.S. It is of interest that this boy's mother was thought by the family and community to have had M.S. for many years, but examination showed that she had longstanding, untreated myasthenia gravis. The relationship of these diseases has been reported recently (Aita et al., 1974).

When the life patterns of these patients were plotted with particular attention to when they lived in and around the area of The Falls, we found that the only time all patients lived in the same vicinity at the same time was during 1951 and 1952. It was thus of some interest that there was an outbreak of polio in 1952 in the area of Tatamagouche, which includes the region under study (Peart et al., 1953). In that community of 628 people, there were 12 paralytic polio cases or $1.9 \%$ of the population, and $47 \%$ of the population had a "polio-like" illness. Eight of the $10 \mathrm{M} . \mathrm{S}$. patients developed their disease in the years following this epidemic and none remembered being ill during it. The evidence for a definite relationship to the polio epidemic in 1952 is not strong, but an association of M.S. with polio has been made in the past by Poskanzer (1963), who noted that the diseases have similar epidemiological, geographical, social, and familial patterns. More recently it was found that polio victims, like M.S. patients, have increased HL-A 3 and HL-A 7 antigens, again suggesting similar etiological mechanisms (Morris and Pietsch, 1973).

Personal contact among patients (except for those related to each other), travel, surgery, (including tonsillectomy), and the use of drugs and patent medications in earlier life could not be definitely related to the high number of M.S. cases. Although many of the patients had Scottish origins, the families had come to the area at least 150 years ago from various parts of Scotland. There did not appear to be anything unusual about the course of the disease or disability rating and pattern of clinical involvement by the Kurtzke scale (Kurtzke, 1963).

\section{Other Community Studies:}

Probably the best known cluster of M.S. was that reported by Campbell et al. (1947) involving four cases in seven men working on swayback 
disease. Campbell et al. (1950) studied lead in relation to M.S. in a number of counties in England and found six cases within 500 yards of each other in a small village in Berkshire. They also found three cases in another village and subsequently two further cases in the same county. They attributed the high incidence of M.S. in this area to the high lead content in the soil and water.

Sutherland (1956) mentions the occurrence of M.S. in three girlfriends, three neighbors in the same street, and two gamekeepers who lived in succession in the same house. In 1959 eight cases of M.S. were found in Duxbury, Massachusetts, population 4,900 (Deacon et al., 1959). Eastman et al. (1974) reported a cluster of 14 cases of M.S. in a population of 10,000 in Mansfield, Massachusetts, 28 miles from Boston. They noted that between 1932 and 1936 all patients were living in Mansfield, most in the same block. They suspected that water contamination during those years was related to the increased percentage of multiple sclerosis patients.

Koch et al. (1974) described a cluster of six cases of M.S. among the 450 people living in Mossyrock, Washington. Similar to our study, all were related in two families. These authors also saw a possible relationship to a smallpox epidemic in 1924 since all the M.S. patients were said to have had smallpox at that time; however, there is confusion about the official documentation of this epidemic and the author suggests that it may have been measles.

Palo and Wikstrom (1973) found increased prevalence of M.S. in western and south western Finland. The clustering of M.S. became even more pronounced when the prevalence by place of birth was analyzed (Wikstrom and Palo, 1975). Wikstrom (1975) noted that all villages with high M.S. frequency in Finland were located along the rivers running through the area. The birthplaces of the patients showed a similar accumulation in the valleys. The authors felt that the number of M.S. cases in certain villages along rivers suggested an exogenous factor in the water, but because the clustering was greater by birthplace than by domicile they also suspected some hereditary factor in the etiology of the disease. Their study revealed that the birthplaces of parents were strikingly concentrated in neighboring villages in the same clerical district. In a subsequent study, Wikstrom examined the increased incidence of tuberculosis in the same areas of Finland that had increased prevalence of M.S. and concluded that perhaps there was a common genetic factor for tuberculosis and M.S. (Wikstrom, 1975).

\section{CONCLUSION}

Although they were factors common to all our patients, we could not place much emphasis on childhood proximity to animals and drinking of unpasteurized milk, abstinance from alcohol and smoking, and the high level of education. The high cholesterol diet may have some relationship, but is extremely difficult to evaluate in retrospect. Of greater interest is the late age at which our patients contracted measles and we believe that this may be a significant factor in explaining the community cluster. We would strongly suggest that the age of contracting viral infections be evaluated carefully in subsequent larger epidemiological studies. The relationship to polio is tenuous, but also bears further evaluation in community studies.

Although we can suggest factors that may have acted as exogenous agents in the community we studied, the most obvious factor relates to the family relationships. Whether this results from a common exposure or genetic predisposition or both is uncertain. Although our community study does not provide any definite answers, it does raise questions for further epidemiological studies on M.S.

McAlpine et al. (1972) thought that if clusters occurred more frequently than by chance alone it would suggest exposure to a common agent or process. Unfortu- nately, whether the clusters reported in M.S. occur by chance cannot be evaluated statistically and such studies are prone to bias. However, the reason for reporting such events is not to prove whether they might occur by chance or not, but to possibly point to factors that may be important in the etiology of M.S. and which could be evaluated in larger epidemiological studies. It is in this spirit that the present community study is reported.

\section{REFERENCES}

AITA, J. F., SNYDER. D. H. and REICHL. W. (1974). Myasthenia gravis and multiple sclerosis: An unusual combination of diseases. Neurology 24: 72-75.

ALTER, M. (1975). Is multiple sclerosis an age-dependent host reaction to measles? Abstract to the 4th Panamerican Congress of Neurology. Mexico City.

CAMPBELL, A. M. G.. DANIEL. P., PORTER, R. J. et al. (1947). Disease of the nervous system occurring among research workers on swayback in lambs. Brain 70 : 50-58.

CAMPBEll, A. M. G., HERDAN, G., TATLOW.W. F. T. et al. (1950). Lead in relation to disseminated sclerosis. Brain 73: 52-71.

DEACON, W. E., ALEXANDER, L.. SIEDLER, H. D. et al. (1959). Multiple sclerosis in a small New England community. New Engl. J. Med. 261: 1059-1061.

EASTMAN, R., SHERIDAN. J. and POSKANZER, D. C. (1974). Multiple sclerosis clustering in a small Massachusetts cum munity with possible common exposure 23 years before onset. New. Engl. J. Med. 289: 793.794

Introductory Nutrition. Edited by $\mathrm{H}$. A. GUTHRIE. (1975). Saint Louis. The C. V. Mosby Company 3rd ed., pp. 40-41.

HAIRE, M., FRASER, K. B. and MILLAR, J. H. D. (1973). Measles and other virusspecific immunoglobulins in multiple sclerosis. Br. Med. J. 3: 612-615.

HAIRE, M.. MILLAR, J. H. D. and MERRETT, J. D. (1974). Measles virus-specific IgG in cerebrospinal fluid in multiple sclerosis. Br. Med. J. 2: 192-193.

KOCH, M. J., REED, D., STERN, R. et al. (1974). Multiple sclerosis. A cluster in a small northwestern United States community. JAMA 228: 1555-1557.

KURTZKE, J. F. (1963). On the evaluation of disability in multiple sclerosis. Neurology 11: 686-694, 1963.

Multiple Sclerosis. A reappraisal. 2nd ed. Edited by D. McALPINE, C. E. LUMSDEN, E. D. ACHESON. (1972). Edinburgh, Churchill Livingstone, 1972. p. 36. 
MORRIS, P. J. and PIETSCH, M. C. (1973). A possible association between paralytic poliomyelitis and multiple sclerosis. Lancet 2: 847-848, 1973.

POSKANZER, D. C., SCHAPIRA, K. and MILLAR, H. (1963). Multiple sclerosis and poliomyelitis. Lancet 2: 917-921.

POSKANZER, D. C. (1968). Etiology of Multiple Sclerosis: analogy suggesting infection in early life. Edited by M. Alter, J. F. Kurtzke, C. C. Thomas Springfield, Illinois, Charles $C$. Thomas Publishing Company.
PALO, J., WIKSTRÖM, J. and KIVALO, E. (1973). Further studies on the epidemiology of multiple sclerosis in Finland. Acta Neurol. Scan. 49: 495-501.

PEART, A. F. W., LAVERS, H., NAGLER, F. P. et al. (1953). A winter outbreak of poliomyelitis in Tatamagouche, Nova Scotia. 1952. Can. J. Public Health 44: 400-406.

SUTHERLAND, J. M. (1956). Observations on the prevalence of multiple sclerosis in Northern Scotland. Brain 79: 635-654.
WIKSTRÖM, J. and PALO, J. (1975). Studies on the clustering of multiple sclerosis in Finalnd I: Comparison between the domiciles and places of birth in selected subpopulations. Acta Neurol. Scand. 51: 85-98.

WIKSTRÖM, J. (1975). Studies on the clustering of multiple sclerosis in Finland II: Microepidemiology in one high-risk county with special reference to familial cases. Acta Neurol. Scand. 51: 173-183.

WIKSTRÖM, J. (1975). The epidemiology of multiple sclerosis and tuberculosis in Finland. A study based on mortality statistics. Acta Neurol. Scand. 52: 207-215. 